\title{
COMPACTION AND WATER INFILTRATION CAPACITY OF A CAMBISOL BY THE TRAFFIC OF MACHINES AND CATTLE TRAMPLING
}

\author{
Romeu Cezar Deon'; Douglas Zilli2; Guilherme Brandelero²; Rafael Goulart Machado ${ }^{3^{*}}$ \\ ${ }^{1}$ Agricultural technician, Emater-RS/ASCAR - Municipal Office of Nova Alvorada, \\ Brazil and Academic of Agronomy, Faculdades IDEAU, Passo Fundo, Brazil; \\ ${ }^{2}$ Academic of Agronomy, Faculdades IDEAU, Passo Fundo, Brazil; \\ ${ }^{3}$ Engineer agronomist, Doctor in Soil Science, Emater-RS/ASCAR - Municipal Office of Coxilha, Brazil and Professor of Agronomy, \\ Faculdades IDEAU, Passo Fundo, Brazil. \\ *Author for correspondence: Rafael Goulart Machado, rgoulartmachado@gmail.com
}

\begin{abstract}
The intensification of agricultural soil exploration by the frequent traffic of machines of increasing weight and by cattle trampling under inadequate soil moisture conditions, has promoted soil compaction and loss of infiltration and water retention capacity. The aim of the present work was to estimate compaction and water infiltration capacity of a very clayey Cambisol under compaction condition induced by the traffic of agricultural machinery and cattle trampling, with soil under field moisture condition and under high soil moisture condition. Soil density, total porosity, water infiltration velocity $(\mathrm{VIB})$ and accumulated water infiltration in the soil were measured after soil compaction induction. An increase in soil density was observed with tractor traffic after rainfall and cattle trampling after rainfall. VIB reduction was observed where soil was compacted by tractor traffic after rainfall. Soil compaction observed by tractor traffic or cattle trampling after rainfall increased soil density, which is directly related to the reduction of total soil porosity. These changes in the proportion of the solid and gaseous soil phases are often associated to restrictions to root growth, restrictions to infiltration and soil water accumulation, and increase soil susceptibility to erosion.
\end{abstract}

KEYWORDS: soil management, soil density, soil porosity, soil degradation

\section{COMPACTAÇÃO E CAPACIDADE DE INFILTRAÇÃO DE ÁGUA DE UM CAMBISSOLO PELO TRÁFEGO DE TRATOR E PISOTEIO BOVINO}

RESUMO: A intensificação da exploração agrícola dos solos pelo trânsito frequente de máquinas de crescente incremento de peso e pelo pisoteio de bovinos, em condições inadequadas de umidade do solo, vem promovendo um estado de compactação dos solos e a perda da capacidade de infiltração e de retenção de água. 0 objetivo do presente trabalho foi dimensionar a compactação e a velocidade de infiltração de água de um Cambissolo muito argiloso em uma condição de compactação induzida pelo tráfego de trator agrícola e pelo pisoteio de bovinos, com solo em condição de umidade de campo e em condição de solo úmido. Após os tráfegos para indução da compactação do solo, foram aferidas a densidade do solo, a porosidade total, a velocidade de infiltração básica da água (VIB) no solo e a infiltração acumulada da água no solo. Foi observado incremento na densidade do solo com tráfego de trator sobre solo após a chuva e tráfego de bovino sobre solo após a chuva. Foi observada redução da VIB onde houve compactação do solo por tráfego de trator sobre solo após a chuva. A compactação observada, por trânsito de trator ou pisoteio de bovinos após a chuva, induziu aumento na densidade do solo o que está diretamente relacionado à redução da porosidade total do solo. Estas alterações na proporção das fases sólida e gasosa do solo, frequentemente estão associadas a restrições ao crescimento radicular das plantas, restrições à infiltração e ao acúmulo de água no solo, bem como à maior suscetibilidade dos solos à erosão.

PALAVRAS-CHAVE: manejo do solo, densidade do solo, porosidade do solo, degradação do solo

\section{INTRODUCTION}

For the good development of cultivated plants, the water availability for the root absorption of plants is fundamental. Water should be slowly made available by soil to plants, according to their growth stage and the demand of each plant species. According to Azevedo 
and Dalmolin (2004), in clayey soils, $40-60 \%$ of the soil volume is occupied by porous space. Micropores, soil pores with diameter smaller than $0.06 \mathrm{~mm}$, are responsible for the storage and subsequent supply of water to plants, while macropores, with diameter greater than $0.06 \mathrm{~mm}$, do not store water and are responsible for soil aeration and water infiltration (Klein and Libardi, 2002). In well structured soils, there is a balance in the proportion of macro and micropores and adequate capacity of storage and supply of water to plants.

According to Denardin et al. (2009), from the decade of 1980s, the no-tillage cropping system was conceptualized as a complex of technological processes for agricultural exploration, considering: soil mobilization, only in the row or sowing pit; permanent maintenance of the soil cover; and species diversification, via crop rotation. According to Silva et al. (2009) in crops under no-tillage cropping system, the environmental impacts of agricultural crops are reduced, with reduction in soil erosion and leaching, as well as carbon sequestration in the soil. On the other hand, the evolution of agriculture promoted the intensification of the soil use with increasingly heavy machines, which causes negative effects on the soil structure, even in the no-tillage system (Collares et al., 2008). According to Castro Neto (2001), soil compaction occurs more strongly in soils subject to high rainfall and irrigation rates, i.e., soil compaction occurs when pressure is exerted by heavy machinery on soils (Lopes et al., 2011).

Soil compaction is a limiting factor to increased productivity and continuous use of notillage cropping system, mainly in clayey soils (Collares et al., 2008). Therefore, optimizing soil use and management is the basis for the sustainability of agricultural production systems. According to Jimenes et al. (2008), in compacted soils, there is an increase in the proportion of micropores in relation to macropores and soil density. As a consequence, there is greater resistance to soil penetration by roots and, due to their limited development, there is a reduction in the volume of soil explored. In addition, the reduction of soil porosity decreases water and oxygen retention and root development of plants. It also favors the increase of nitrogen loss due to the denitrification process (Floss, 2011).

The aim of the present work was to estimate the compaction and water infiltration velocity of a very clayey Cambisol under compaction condition induced by agricultural tractor traffic and cattle trampling under different soil moisture conditions.

\section{MATERIAL AND METHODS}

The experiment was carried out in rural property located in the community of São Vitor, municipality of Camargo, Rio Grande do Sul, in a field under no - tillage cropping system for more than 15 years, with soybean / ryegrass succession. Treatments were carried out during the post-harvest period of the soybean crop (Glycine max L.), with dry mass cover of approximately $3 t$ ha${ }^{1}$, composed exclusively of soybean stubble. According to Streck et al. (2008), the soil is classified as a typical Eutrophic Haplic Cambisol and presents $61.2 \%$ of clay, $25 \%$ of silt and $13.8 \%$ of sand by the densimeter method (Bouyoucos, 1951; Embrapa, 1997), being classified as very clayey texture, according to Lemos and Santos (1984).

The experiment was installed in a completely randomized design with four treatments and four replicates. The four treatments were composed of different soil compaction conditions: treatment composed of tractor traffic after rainfall with duration of 24 hours and volume of $80 \mathrm{~mm}$; cattle trampling after rainfall with duration of 24 hours and volume of $80 \mathrm{~mm}$; tractor traffic before rainfall; control treatment without compaction.

Soil moisture was determined at the time of each treatment, soil volumetric moisture (\%) was determined, as described by Embrapa (1997). After collection, samples were oven dried at $1050 \mathrm{C}$ for 24 hours. Volumetric soil moisture was determined by subtracting the wet sample weight (before drying) by the dry sample weight and dividing the product of this subtraction by the sample volume, according to the formula below:

\section{Volumetric soil moisture $=(\%)=100 *$ (wet sample weight (g) - dry sample weight (g)) / sample volume $(\mathrm{cm} \mathrm{3)}$}

At the time prior to the $80 \mathrm{~mm}$ rainfall, when the tractor traffic treatment was conducted prior to rainfall, the soil moisture content was $267 \mathrm{~mL}$ of water per liter of soil, equivalent to $26.7 \%$. After the $80 \mathrm{~mm}$ rainfall at the moment of cattle trampling after rainfall and tractor traffic after rainfall treatments, the soil moisture content was $387 \mathrm{~mL}$ of water per liter of soil, equivalent to $38.7 \%$. 
Soil compaction induction by tractor traffic was done with the passage of a tractor, and soil sample collections were made in a position of recurrence of the front and rear tires, at the point of greatest pressure of tires on the soil, at its most rigid extremity, the diagonal band. The tractor used was a Massey Fergusson MF 291 $4 \times 4$, year 2009, which according to the manufacturer's description, has total weight of $6,245 \mathrm{~kg}$. The static weight division is $2,513 \mathrm{~kg}$ on the front axle, $1,265.5 \mathrm{~kg}$ on each wheel, and $3,732 \mathrm{~kg}$ on the rear axle, $1,866 \mathrm{~kg}$ on each wheel. Regarding soil compaction induction by cattle trampling, soil samples were collected after the traffic of cattle (Bos taurus), at the point where there was recurrence of trampling of the front legs with the hind legs. The caw used was a Holstein cow weighing $500 \mathrm{~kg}$.

Four soil samples collected from 0 to $5 \mathrm{~cm}$ in depth were sampled in each treatment, three days after the $80-\mathrm{mm}$ rainfall. For this, rings of $5 \mathrm{~cm}$ in depth and $97 \mathrm{~cm}^{3}$ in volume were used. For each of these samples, the following parameters were determined: soil density $\left(\mathrm{g} \cdot \mathrm{cm}^{-3}\right)$, density of solids $\left(\mathrm{g} . \mathrm{cm}^{-3}\right)$ and total soil porosity (\%).

Soil compaction levels were determined by soil density. This method is applicable, since soil compaction approaches solid particles that compose it, reducing porous spaces, increasing its density. For this, the volumetric cylinder method known as "Kopeck Ring" was used (Kiehl, 1979; Klein, 2012). After drying in laboratory at temperature of $105^{\circ} \mathrm{C}$ for a period of 24 hours, samples were weighed to determine the dry mass of solids. Dividing the dry mass of solids by the volume of cylinders, the soil density in all treatments was obtained (Troeh and Thompson, 2007, Klein 2012), according to the following formula:

Soil density $(\mathrm{g} . \mathrm{cm}-3)=$ dry weight of solids $(\mathrm{g}) /$ volume of cylinders (cm3)

To determine the density of solids, the volumetric flasks method was used. Calibrated $50 \mathrm{~mL}$ volumetric flasks were used. In each flask, 20 grams of dry soil were added and the volume of $50 \mathrm{ml}$ of each flask was then filled with alcohol as described by Klein (2012). The density of solids was calculated according to the formula below:
Density of solids (g.cm-3) $=$ dry soil mass / (flask volume - volume of alcohol added)

The total soil porosity was determined by the difference between soil density and the density of solids, according to the formula below, described by Klein (2012).

\section{$a=100$ * $[1$ - (Soil Density / Density of Soil Solids)]}

The soil water infiltration velocity (VIB) was evaluated in the Control Treatment without compaction and for comparison purposes, VIB in the tractor traffic on humid soil treatment was also evaluated, with four replications per treatment. In the cattle trampling after rainfall and tractor traffic before rainfall treatments, no compaction (increase in soil density) was observed other than the tractor traffic after rainfall treatment. In this way, it was considered, for the study objectives, only the VIB measurement in the control treatment and in the tractor traffic after rainfall treatment.

The VIB verification technique, adapted from Bernardo et al. (2006), consisted of the introduction of a PVC cylinder of $150 \mathrm{~mm}$ in diameter and $450 \mathrm{~mm}$ in height. The cylinder was introduced $15 \mathrm{~cm}$ deep into the soil, with constant pressure to reach the desired depth. The constant pressure for the introduction of the cylinder reduces its misalignment, as well as the lateral pressure to the ground, which could cause a crack between the ground and the cylinder wall. For this purpose, a hydraulic jack was used, supported on the cylinder, using the ballast of an agricultural tractor on it in order to exert resistance to the hydraulic force of the jack, pushing the cylinder down.

Data were submitted to analysis of variance and test of means (Duncan, 5\%), using the SISVAR statistical software (Ferreira, 2000).

\section{RESULTS AND DISCUSSION}

There was an increase in soil density and reduction of total soil porosity in tractor traffic after rainfall (T3) and cattle trapping after rainfall treatments (T4), which indicates changes in the physical soil structure to a condition of greater compaction (Table 1). Cattle trampling after rainfall treatment (T4) induced higher soil density, not differing from tractor traffic after rainfall 
(T3) and tractor traffic before rainfall treatments (T2). The control treatment (T1) was the one with the lowest soil density, but there was no difference between this treatment and tractor traffic before rainfall treatment $(\mathrm{T} 2)$.

With the results presented in Table 1, it was possible to infer that in tractor traffic after rainfall and cattle trampling after rainfall treatments (humidity of $38.7 \%$ ), soil density increases were significant compared to control treatment (T1). According to Klein and Libardi (2002), changes in soil density due to management promote lower soil moisture at the point of saturation and higher soil moisture at the permanent wilting point, which means lower proportion of water available under conditions of water stress.

Table 1. Soil density after soybean harvest with induced compaction.

\begin{tabular}{ccc}
\hline Treatments & $\begin{array}{c}\text { Dry soil weight }(\mathrm{g}) \\
\text { Vol. } 97 \mathrm{~cm}^{3}\end{array}$ & $\begin{array}{c}\text { Density } \\
\left(\mathrm{g} \cdot \mathrm{cm}^{-3}\right)\end{array}$ \\
\hline Cattle trampling after rainfall & 119.892 & $1.236 \mathrm{a}^{*}$ \\
Tractor traffic after rainfall & 117.467 & $1.211 \mathrm{a}$ \\
Tractor traffic before rainfall & 111.162 & $1.146 \mathrm{ab}$ \\
Control treatment, without traffic & 101.074 & $1.042 \mathrm{~b}$ \\
\hline
\end{tabular}

Coefficient of variation (CV\%)

2.62

* Values referring to averages of four replicates. Values differ among themselves at $5 \%$ error probability level according to Duncan's test.

On the other hand, tractor traffic before rainfall treatment did not present significant changes in soil density compared to the control treatment. These results indicate that, despite the load on the soil surface with the tractor wheels before rainfall ( $26.7 \%$ humidity), soil compaction due to tractor traffic was not significant.

Andrade and Stone (2011) quantified the moisture content of soils with different textures when in field capacity. In very clayey soils, as in the present study, the authors observed moisture content of $40.9 \%$. Based on the above, we estimate that in the present study, soil moisture after rainfall, compaction time by tractor traffic after rainfall (T3) and cattle trampling after rainfall (T4) was approximately $95 \%$ of the field capacity, while in tractor traffic before rainfall treatment (T2), it was $65 \%$ of field capacity. Thus, this $30 \%$ less humidity compared to field capacity, observed in the tractor before rainfall treatment (T2), had great importance, because despite tractor traffic before rainfall, there was no difference in density in T2 compared to control treatment, and this is due to the lower soil moisture content at the compaction time.

For a given compaction energy, there is a great influence of soil moisture on the effect on soil compaction (Ohu et al., 1989; Braida et al., 2006). According to Braida et al. (2006), for the same compaction energy, soil density depends on soil moisture, since density increases with increasing humidity until a certain value and then decreases. This behavior is explained by the behavior of water in the soil, which at low humidity, forms a water film around mineral particles, reducing the friction between them, facilitating the rearrangement of particles and consequent compaction.

Thus, the higher the soil density, the lower the total soil porosity, which can be calculated from the specific mass of particles common in the soil composition and soil specific mass. The solid particulates that compose the soil are of mineral or organic origin, having different densities. According to Troeh and Thompson (2007), for the conditions of tropical and subtropical soils, in the calculation of total porosity, one can assume the average value of the specific mass of particles of $2.65 \mathrm{~g} . \mathrm{cm}^{3}$. The total soil porosity was determined in the different treatments studied, as well as the relationship of porosity of treatments compared to the control treatment (Table 2). It was observed that the relationship between the increase in soil compaction and the decrease in total soil porosity is directly proportional. In cattle trampling after rainfall treatment (T4), the highest soil density and the lowest total soil porosity were verified (Tables 1 and 2). A very similar condition was observed in the tractor traffic after rainfall treatment (T3). In the cattle trampling after rainfall treatment, 0.88 of the total porosity was observed in relation to the control treatment, or $53.33 \%$ of total soil porosity, while in the control treatment, $60.67 \%$ of total soil porosity was observed (Table 2). In the tractor traffic after rainfall treatment, 0.90 of total soil porosity was observed in relation to control treatment, or $54.30 \%$ of total soil porosity, against $60.67 \%$ of control treatment. 
Table 2. Total soil porosity in post-harvest soybean, with induced compaction.

\begin{tabular}{ccc}
\hline Treatments & Total porosity $(\%)$ & Porosity in relation to Control (T1) \\
\hline Control treatment, without traffic & $60.67 \mathrm{a}^{*}$ & 1.00 \\
Tractor traffic before rainfall & $56.75 \mathrm{~b}$ & 0.94 \\
Tractor traffic after rainfall & $54.30 \mathrm{~b}$ & 0.90 \\
Cattle trampling after rainfall & $53.33 \mathrm{~b}$ & 0.88 \\
\hline
\end{tabular}

* Values referring to averages of four replicates. Values differ among themselves at $5 \%$ error probability level according to Duncan's test.

In tractor traffic after rainfall and cattle trampling after rainfall treatments, an increase in soil compaction is verified, as density increases. At the same time that soil density increases in these treatments, a reduction in total soil porosity is verified. These indicatives determine the reduction in the capacity of compacted soil to contain water and air in its composition, being potentially restrictive for good root growth, water supply, aeration and nutrient supply for cultivated plants.

As a result of the increase in soil compaction, there is a higher energy demand for soil mobilization (Mentges et al., 2010) and mainly increased resistance to soil colonization by roots (Stone et al., 2002; Denardin, 2018), and water infiltration becomes compromised (Stone et al., 2002). In this sense, some authors, such as Rosa Filho et al. (2009) consider the increase in soil density as a limitation to crop yield. Thus, it is necessary to plan activities in rural properties, so as not to submit soil to heavy loads, especially when they are in a high humidity condition.
The soil water infiltration velocity (VIB) and accumulated water infiltration rates for tractor traffic after rainfall (T3) and control treatments (T1) were compared. Figure 1 shows the water infiltration in the soil chart, up to constant water infiltration rate (Figure 1). There was a great difference in the water infiltration velocity in the different treatments, and throughout the evaluation period, the water infiltration in the soil in the tractor traffic after rainfall treatment was much lower compared to the control treatment. The great difference in the water infiltration velocity in the different treatments was remarkable in the first 5 minutes of evaluation, where the soil of the control treatment had infiltration of $18 \mathrm{~mm}$, equivalent to $216 \mathrm{~mm}$ $\mathrm{h}$, against $10 \mathrm{~mm}$ of tractor traffic after rainfall treatment, which is equal to $120 \mathrm{~mm} / \mathrm{h}$. In the interval between 5 and 10 minutes of infiltration in the tractor traffic after rainfall treatment, only $4 \mathrm{~mm}$ of water infiltration in the soil, equivalent to $48 \mathrm{~mm} / \mathrm{h}$, is observed. For the tractor traffic after rainfall treatment, constant infiltration was obtained at 25 minutes, from which constant infiltration of $24 \mathrm{~mm} / \mathrm{h}$ was maintained (Figure 1).

Figure 1. Water infiltration rate in soil in Control and Tractor treatments in soil with high moisture content

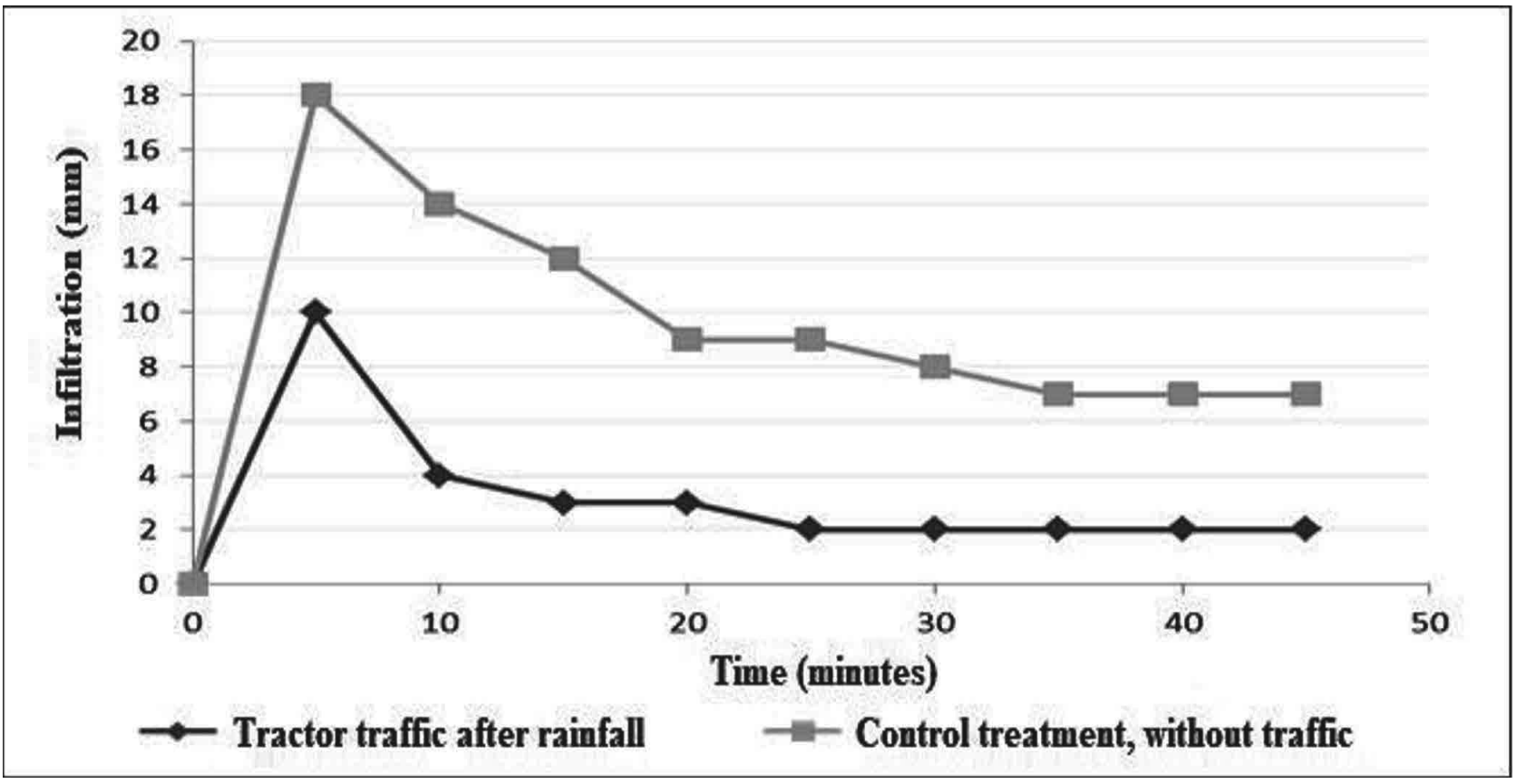


On the other hand, in the control treatment (T1), there was infiltration of $14 \mathrm{~mm}$ in the interval from 5 to 10 minutes. In the control treatment, the reduction of infiltration rate was slower, reaching stability only at 35 minutes, maintaining a constant infiltration rate of $7 \mathrm{~mm}$, equivalent to $84 \mathrm{~mm} \mathrm{h-1}$. Thus, the water infiltration rate in the control treatment (T1) was 3.5 times higher than the treatment with compacted soil (T3) (Figure 1).

In the tractor traffic after rainfall treatment (T3), after water had flooded macropores, its infiltration was limited by the soil surface compaction layer, induced by the traffic of the tractor. Thus, the infiltration limitation is attributed to the compacted soil strip, inducing less water passage through its pores, as observed in figure 1. The lower soil capacity to allow water infiltration observed in treatment T3 can significantly contribute to the increase in the incidence of soil erosion, especially if it is associated with the absence of straw on the surface and on sloping ground (Bertoni and Lombardi Neto, 1985; da Costa, 2005). In addition to the benefits associated with root growth and nutrient input in deeper layers, the conservation of good soil porosity also contributes to better soil conservation, since the larger the volume of water infiltrated, the less water will be to runoff. In this sense, soil porosity is an important feature for the mitigation of erosive processes, both in conventional and no-tillage cropping systems.

Figure 2 shows the accumulated infiltrations in control (T1) and tractor traffic after rainfall treatments (T3) over 45 minutes. It is possible to verify greater soil infiltration in the control treatment compared to soil with induced compaction, where the accumulated infiltration of the control treatment at 45 minutes is of $91 \mathrm{~mm}$, whereas in the tractor traffic after rainfall treatment, 30 $\mathrm{mm}$ of accumulated infiltration were observed.

Figure 2. Accumulated water infiltration in soil in tractor and control treatments in soil with high moisture content

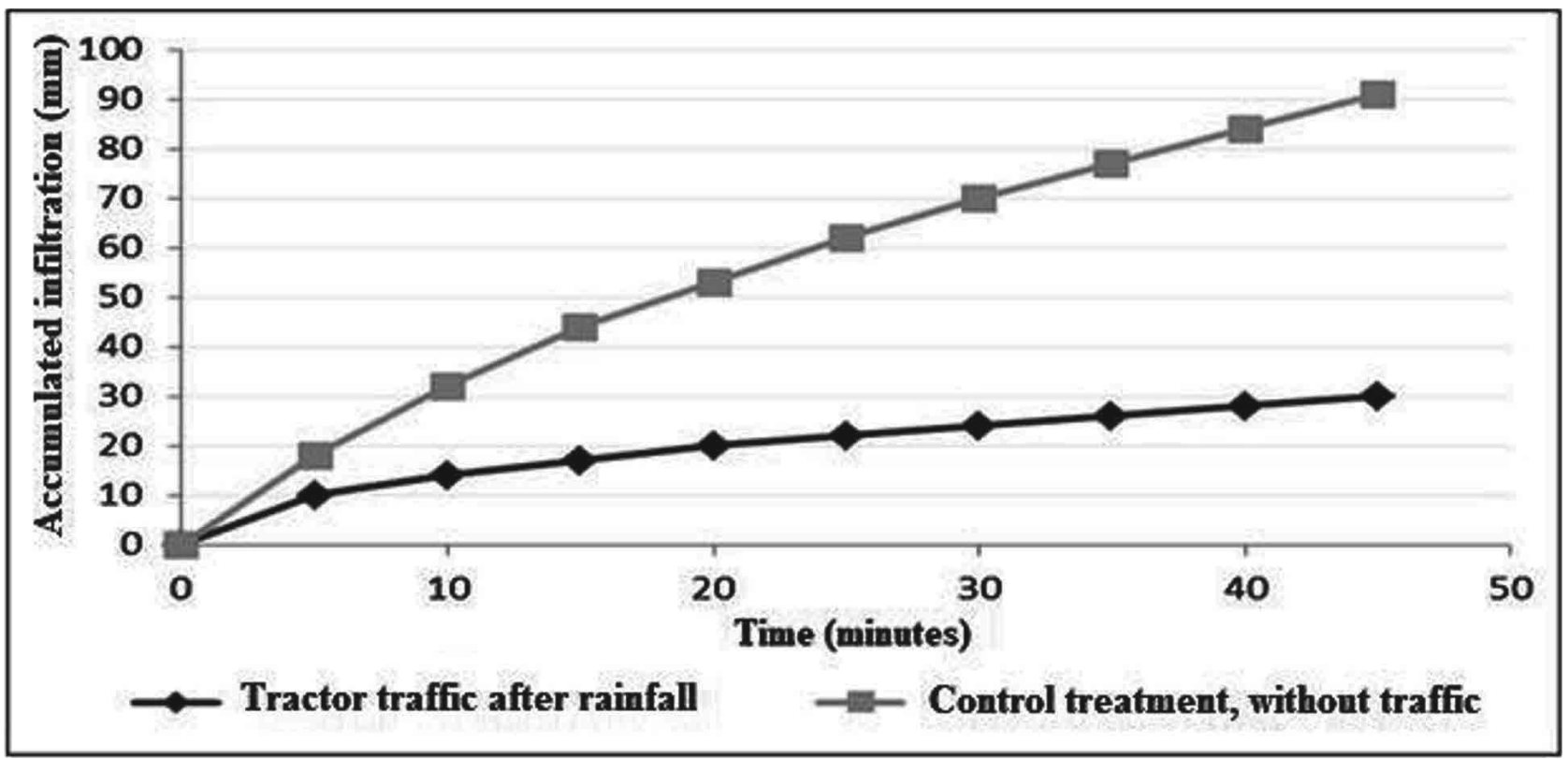

The measurement of the accumulated water infiltration in soil provides the dimensioning of the importance of the soil structure and its fundamental participation as part of erosion control and conservation of soil fertility conditions, as well as the water and air storage capacity. The water infiltration in soil with induced compaction was $61 \mathrm{~mm}$ less than in the control treatment during the 45 minutes of observation. In this sense, the restriction to soil water infiltration due to compaction provides a condition for water runoff and soil erosion, with nutrient losses, and can even cause root diseases or death of plants by asphyxiation (Filizola, 2012).

In this way, it could be concluded that there is no difference between soil densities when compacted by tractor traffic before rainfall; tractor traffic after rainfall; or cattle trampling after rainfall. Greater soil compaction occurs with tractor traffic after rainfall and cattle trampling after rainfall, compared to soil without compaction.

Lower soil water infiltration velocity (VIB) and lower accumulated infiltration with tractor traffic after rainfall are observed, compared to soil without compaction. 


\section{REFERÊNCIAS BIBLIOGRÁFICAS}

Andrade, R.S.; Stone, L.F. Estimativa da umidade na capacidade de campo em solos sob Cerrado. Revista Brasileira de Engenharia Agrícola e Ambiental, 2011, 15, 111-116.

Azevedo, A.C.; Dalmolin, R.S.D. Solos e ambiente: uma introdução. Pallotti: Santa Maria, Rio Grande do Sul, 2004. $100 \mathrm{p}$.

Bernardo, S; Soares, A.A.; Mantovani, E.C. Manual de irrigação. UFV: Viçosa, Minas Gerais, 2006. 625p.

Bertoni, J.; Lombardi Neto, F. Conservação do solo. Livroceres: Piracicaba, São Paulo, 1985. 368 p.

Bouyoucos, G.J. A recalibration of the hydrometer method for making mechanical analysis of soil. American Society of Agronomy Journal, 1951, 43, 434-438.

Braida, J.A.; Reichert, J.M.; Veiga, M.; Reinert, D.J. Resíduos vegetais na superfície e carbono orgânico do solo e suas relações com a densidade máxima obtida no ensaio proctor. Revista Brasileira de Ciência do Solo, 2006, 30, 605-614.

Castro Neto, P. Desenvolvimento e avaliação de equipamentos e metodologia para determinação de parâmetros físicos do solo relacionados a dias trabalháveis com máquinas agrícolas. Tese (Doutorado em Agronomia/Energia na Agricultura) Faculdade de Ciências Agronômicas, Universidade Estadual Paulista: Botucatu, São Paulo, 2001. 155 p.

Collares, G.L.; Reinert, D.J.; Reichert, J.M.; Kaiser, D.R. Compactação de um latossolo induzida pelo tráfego de máquinas e sua relação com o crescimento e produtividade de feijão e trigo. Revista Brasileira de Ciência do Solo, 2008, 32, 933-942.

Da Costa, A.L.C. Estudo da vulnerabilidade à erosão com a aplicação da Equação Universal da Perda de Solo na Alta Bacia Hidrográfica do Rio Jacaré Pepira, utilizando SIG/SPRING (Dissertação de Mestrado) - Universidade Estadual Paulista, Instituto de Geociências e Ciências Exatas: Rio Claro, São Paulo, 2005. $167 \mathrm{p}$.
Denardin, J.E.; Faganello, A.; Santi, A. Falhas na implantação do sistema plantio direto. A Lavoura, 2009, $112,20-22$.

Denardin, J.E. Compactação e adensamento do solo: caracterização, origem, riscos, danos e soluções. Embrapa Recursos naturais: Brasília, Distrito Federal, 2018. Acesso em: https://www.embrapa.br/busca-denoticias/-/noticia/31340322/artigo---compactacao-eadensamento-de-solo-caracterizacao-origem-riscosdanos-e-solucoes

Embrapa. Manual de métodos de análise de solo 2. ed. Centro Nacional de Pesquisa de Solos: Rio de Janeiro, Rio de Janeiro, 1997. 212 p.

Ferreira, D.F. Sistemas de análise estatísticas para dados balanceados. UFLA/DEX/SISVAR: Lavras, Minas Gerais, 2000. 145 p.

Filizola, H.F. Compactação e erosão do solo, p. 7576. In: Educação Ambiental para o Desenvolvimento Sustentável - Julgar Percepção do Impacto Ambiental 3. ed. Hammes, V.S., Embrapa: Brasília, Distrito Federal, 2012. $286 \mathrm{p}$.

Floss, E.L. Fisiologia das Plantas: o estudo que está por trás do que se vê. UPF: Passo Fundo, Rio Grande do Sul, 2011. 734 p.

Jimenez, R.L.; Gonçalves, W.G.;Araújo Filho, J.V.;Assis, R.L.; Pires, F.R; Silva, G.P. Crescimento de plantas de cobertura sob diferentes níveis de compactação em um latossolo vermelho. Revista Brasileira de Engenharia Agrícola e Ambiental, 2008, 12, 116-121.

Kiehl, E.J. Manual de edafologia. Relações solo-planta. Ceres: São Paulo, São Paulo, 1979, 264 p.

Klein, V.A. Física do solo. Editora UPF: Passo Fundo, Rio Grande do Sul, 2012, 2. ed., 240 p.

Klein, V.A.; Libardi, P.L. Densidade e distribuição do diâmetro de poros de um Latossolo Vermelho, sob diferentes sistemas de uso e manejo. Revista Brasileira de Ciência do Solo, 2002, 26:857-867.

Lemos, R.C.; Santos, R.D. Manual de descrição e coleta de solo no campo. Sociedade Brasileira de 
Ciência do Solo/Serviço Nacional de Levantamento e Conservação de Solos: Campinas, São Paulo, 1984. $45 \mathrm{p}$.

Lopes, E.S.; Sampietro, J.A.; Lombardi, K.C.; Dias, A.N. Avaliação da umidade na compactação do solo submetido ao tráfego de máquinas de colheita florestal. Revista Árvore, 2011, 35, 659-667.

Mentges, M.I.; Reichert, J.M.; Rosa, D.P.; Vieira, D.A.; Rosa, V.T.; Reinert, D.J. Propriedades físico-hídricas do solo e demanda energética de haste escarificadora em Argissolo compactado. Pesquisa Agropecuária Brasileira, 2010, 45, 315-321.

Ohu, O.J.; Folorunso, O.A.; Raghavan, G.S.V. e Adeniji, F.A. Critical content as an index of compactability of agricultural soils in Borno state of Nigeria. Soil Technology, 1989, 2, 211-219.

Rosa Filho, G.; Carvalho, M. P.; Andreotti, M.; Montanari, R.; Binotti, F.F.S.; Gioia, M.T. Variabilidade da produtividade da soja em função de atributos físicos de um Latossolo Vermelho Distroférrico sob plantio direto. Revista Brasileira de Ciência do Solo, 2009, 33, 283-293.
Silva, A.A.; Galon, L.; Ferreira. F.A.; Tiron, S.P.; Ferreira, E.A.; Silva, A.F.; Aspiazú, I.; Agnes, E.L. Sistema de plantio direto na palhada e seu impacto na agricultura brasileira. Revista Ceres, 2009, 56, 496-506.

Stone, L.F.; Guimarães, C.M.; Moreira, J.A.A. Compactação do solo na cultura do feijoeiro. I: efeitos nas propriedades físico-hídricas do solo. Revista Brasileira de Engenharia Agrícola e Ambiental, 2002, 6, 207-211.

Streck, E.V.; Kämpf, N.; Dalmolin, R.S.D.; Klamt, E.; Nascimento, P.C.; Schneider, P.; Giasson, E.; Pinto, L.F.S. Solos do Rio Grande do Sul. EMATER/RS: Porto Alegre, Rio Grande do Sul, 2008. 222 p.

Troeh, F.R.; Thompson, L.M. Propriedades físicas do solo, p. 63-104. In: Solos e Fertilidade do Solo. 6 ed. Troeh, F.R. and Thompson, L.M., Andrei: São Paulo, São Paulo, 2007. 718 p. 